\title{
Analysis of Causes of Hospitalization Among Children with Sickle Cell Disease in a Group of Private Hospitals in Jeddah, Saudi Arabia
}

\author{
Shereen M Abd El- \\ Ghany $\mathbb{D}^{1,2}$ \\ Aisha T Tabbakh ${ }^{3}$ \\ Khulud I Nur (D) ${ }^{3}$ \\ Rayan Y Abdelrahman ${ }^{3}$ \\ Sara M Etarji ${ }^{3}$ \\ Bayan Y Almuzaini ${ }^{3}$ \\ 'Department of Pediatrics, Ibn Sina \\ National College for Medical Studies, \\ Jeddah, Kingdom of Saudi Arabia; \\ ${ }^{2}$ Department of Pediatrics, Hematology \\ and Oncology Unit, Ain Shams University, \\ Cairo, Egypt; ${ }^{3}$ College of Medicine, Ibn \\ Sina National College for Medical Studies, \\ Jeddah, Kingdom of Saudi Arabia
}

Purpose: Sickle cell anemia (SCA) is a chronic hematologic condition that requires frequent hospitalization representing a significant economic burden on the health services. The aim of this study was to explore the causes and underlying factors of hospitalization among children with SCA, as well as the factors affecting their length of hospital stay.

Patients and Methods: This retrospective study included children and adolescents less than 16 years old who were admitted in a group of private hospitals in Jeddah, Saudi Arabia, during the period from January 2018 to December 2019.

Results: A total of 94 patients were included in this study, 59.6\% were males, with a mean age $7.29 \pm 3.82$ years. The majority of the patients $(91.5 \%)$ had sickle cell disease. The most common cause of hospital admission was vaso-occlusive crises (VOC) (64.9\%) followed by infection (24.5\%), acute chest syndrome (ACS) (18.1\%), and acute hemolytic crisis $(12.8 \%)$. We found no significant difference between gender and different causes of admissions $(\mathrm{p}>$ $0.05)$. While in relation to age group, limb pain and back pain were found to be significantly more frequent among children $\geq 7$ years old $(\mathrm{p}=0.03,0.04)$, while infections were significantly more frequent among children $<7$ years old $(\mathrm{p}=0.003)$. We analyzed the length of hospital stay and different factors, and we found that the mean length of hospital stay was significantly higher among children who were admitted with infections $(p=0.01)$ and ACS $(\mathrm{p}<0.001)$ and among children who are non-compliant on hydroxyurea $(\mathrm{p}=0.04)$.

Conclusion: The most common cause of hospitalization among children with SCD in Jeddah, Saudi Arabia, was VOC followed by infection, ACS and acute anemia. The length of hospital stay was more prolonged among children with infection and ACS, as well as children who were non-compliant to hydroxyurea.

Keywords: vaso-occlusive crisis, acute chest syndrome, infection, hydroxyurea

\section{Introduction}

Sickle cell anemia (SCA) is an autosomal recessive worldwide genetic disorder. That is caused by single point mutation in the gene encoding the $\beta$-globin chain of hemoglobin. This disorder affects many organs in the human body with high morbidity and mortality rates. Those patients also suffer a poorer quality of life than others. ${ }^{1}$ In this disease, red blood cells become sickle shaped due to a hemoglobin gene mutation forming what is called sickle hemoglobin ( $\mathrm{Hb} \mathrm{S}$ ). These irregularly shaped blood cells are very viscous causing them to get stuck in blood vessels at different sites and block or sluggish the circulation to the various organs. As a result of this sluggish circulation, pain and damage to the organs can occur. ${ }^{2}$
Correspondence: Shereen M Abd El-Ghany Department of Pediatrics, Ibn Sina Nationa College for Medical Studies, Ghulail District, Al Mahjar St., Jeddah, 2242I Kingdom of Saudi Arabia

Tel +966540437238

Fax +966126368194

Email shereen22eg@yahoo.com 
SCA is found in almost all the world especially the Mediterranean countries, African, South and Central America in addition to Middle Eastern countries. ${ }^{1}$ Many Arab countries reported the presence of SCA in different countries with different prevalence. In Qatar and Oman, the prevalence was $(3.9 \%$ and $3.8 \%)$ respectively. In the United Arab Emirates, it reaches about $1.9 \%{ }^{3}$ The situation in Saudi-Arabia is different. SCA is reported as one of the significant health issues among children there. The prevalence of SCA differs according to the region with the highest prevalence was reported in the Eastern regions $(0.17 \%)$ while in the Southern areas, and in Al Madinah, it was only $(0.01 \%) .{ }^{4,5}$ Although the mutation in patients with SCD is the same. However, clinically it is very diverse, ranging from a severe, life threatening state to a benign, almost asymptomatic form. In Saudi Arabia, the clinical phenotype of SCD has two major forms. In the Eastern province, where the Saudi-Indian haplotype is prevalent, the disease has mild features in which splenic complications and bone pathology are more common. In addition, painful crisis and vasculopathy occur at a later age. However, the disease in the Western province is more severe, consistent with the Benin haplotype. ${ }^{6}$

Patients with SCA suffer from chronic hemolytic anemia which can lead to sudden life-threatening events. This is usually triggered by acute sickling of red blood cells and microvascular occlusion resulting in pain or damage to organs especially when there are repeated attacks. ${ }^{7}$ Severe complications of SCA in most of cases require hospitalization which represents a burden on both the health care system and the family. Also, sickle cell patients report poorer quality of life $(\mathrm{QoL})$ in comparison with the general population and other chronic non-communicable diseases. $^{8-10}$

The hospital admission pattern of children with SCA varies in different parts of the world. The most common causes of hospitalization in these cases include painful crisis and infection. Also acute sequestration crisis and acute chest syndrome were reported in many cases. In addition, the hospitalization may be for receiving blood transfusions for anemia. ${ }^{11}$

One of the most useful preventive measures from SCA complications is the neonatal screening programs. These programs allow early initiation of prophylactic vaccinations. Also screening with transcranial Doppler ultrasonography annually is recommended in addition to the use hydroxyurea. ${ }^{12}$ So, the present study was conducted to explore the causes of hospitalization among children with
SCA in a group of private hospitals in Jeddah, Saudi Arabia, as well as, the factors underlying their length of hospital stay.

\section{Patients and Methods}

This was a retrospective study which was conducted at Ibn Sina, Al Jedaani Al Safa and New Al Jedaani Hospitals in Jeddah. The present study included all children and adolescents below the age of 16 years with Sickle cell disease who were admitted to Ibn Sina Hospital and Al Jedaani Hospitals in the period from January 2018 to December 2019. We excluded patients with incomplete data and patients with sickle cell trait. Data were held confidentially. This study was conducted in accordance with the Code of Ethics of the World Medical Association (Declaration of Helsinki) for experiments in humans. This study was approved by the Ethical committee of Ibn Sina National College for medical Sciences. Informed consent was not needed because the study was conducted retrospectively. Patients' data obtained from the medical records were kept confidential. The enrolled patients were divided into two groups: group 1: included children $<7$ years old and group 2 : included children $\geq 7$ years old.

\section{Data Collection}

Clinical data was obtained by reviewing patients' Hospital electronic files. Data collection sheets included: sociodemographic data (age at presentation, gender, nationality and provenance area), diagnosis, medications (Oral penicillin V [ospen], folic acid and hydroxyurea), data related to the current admission including: cause of admission (vaso-occlusive crisis, acute chest syndrome, infection, hemolytic crisis and blood transfusion), clinical examination (pallor, jaundice and hepatomegaly \pm splenomegaly), complete blood count, outcome (discharge with complete recovery, discharge with disability or death), number and causes of previous hospitalizations and history of previous operations. Recurrent admissions was defined as $\geq 3$ admissions/year. Vasoocclusive crises are episodes usually present with sudden onset of severe pain, often localized to the extremities, chest, back or abdomen. VOC is the result of obstruction and reduction of the blood flow to the vital organs by the sickled red blood cells leading to ischemia, necrosis and pain. ${ }^{13}$ 


\section{Data Management}

The collected data were coded, entered, presented, and analyzed by computer using Statistical Package for Social Science (version 22, SPSS Inc., Chicago, IL) software program. Quantitative variables were expressed as the mean \pm standard deviation (SD) while the qualitative variables were expressed as a number and percentage. Independent $t$-test was used to compare the difference between two means. Chi-square test was used to detect the relation between different qualitative variables. The results were considered statistically significant when the significant probability (P value) of $<0.05$.

\section{Results}

This study included 94 children and adolescents with sickle cell disease. We excluded three patients with sickle cell trait and one patient who was admitted for tonsillectomy. Of these patients, 56 (59.6\%) were males and $38(40.4 \%)$ were females with a median age of 7.65 (ranged from seven months to 14 years). Patients were divided into two age groups: $40(42.6 \%)$ patients were $<$ 7 years old and $54(57.4 \%)$ patients were from $\geq 7$ to 14 years old. Most of the admitted patients had sickle cell anemia $(91.5 \%)$ and only $8.5 \%$ of them had sickle/ $\beta$ thalassemia. Regarding the long-term treatment modalities; $61(64.9 \%)$ children were on regular folic acid tablets, 37 (39.4\%) children were taking oral penicillin $\mathrm{V}$ (ospen) daily and 30 (31.9\%) children were taking hydroxyurea (HU) (Table 1). Regarding treatment given during the admission, all patients received intravenous fluids, 61 patients $(64.9 \%)$ received analgesics, 23 patients $(24.5 \%)$ received antibiotics and 29 patients $(30.9 \%)$ needed blood transfusion. All patients were discharged safely from the hospital with complete recovery.

The causes of hospital admissions of the studied children are demonstrated in Figure 1. In this study, the most common cause of hospitalizations among our children was vaso-occlusive crisis (VOC) (64.9\%), 45.7\% of them presented with pain in the limbs (Figure 2). Infections represent the second cause of hospitalizations among our patients $(24.5 \%)$ in the form of herpetic stomatitis, viral upper respiratory tract infections, severe gastroenteritis, encephalitis and osteomyelitis. The third cause of hospitalization was acute chest syndrome (18.1\%). Acute hemolytic crisis represented $12.8 \%$ of the causes of hospitalization.
Table I Basic Characteristics of the Studied Group

\begin{tabular}{|c|c|c|}
\hline \multirow[t]{2}{*}{ Basic Characteristics } & \multicolumn{2}{|c|}{$\begin{array}{l}\text { Study Group } \\
(n=94)\end{array}$} \\
\hline & Number & $\%$ \\
\hline \multicolumn{3}{|l|}{ Age } \\
\hline$<7$ years & 40 & 42.6 \\
\hline$\geq 7-14$ years & 54 & 57.4 \\
\hline \multicolumn{3}{|l|}{ Sex } \\
\hline Male & 56 & 59.6 \\
\hline Female & 38 & 40.4 \\
\hline \multicolumn{3}{|l|}{ Nationality } \\
\hline Saudi & 51 & 54.3 \\
\hline Non-Saudi & 43 & 45.7 \\
\hline \multicolumn{3}{|l|}{ Diagnosis } \\
\hline$S C D$ & 84 & 89.4 \\
\hline Sickle thalassemia & 10 & 10.6 \\
\hline \multicolumn{3}{|l|}{ Treatment Modalities } \\
\hline Oral penicillin $\vee$ (ospen) & 37 & 39.4 \\
\hline Folic acid tablets & 61 & 64.9 \\
\hline Hydroxyurea & 30 & 31.9 \\
\hline \multicolumn{3}{|l|}{ Blood transfusion } \\
\hline Regular & 26 & 27.7 \\
\hline On demand & 68 & 72.3 \\
\hline Length of hospitalization (days) $($ mean \pm SD) & \multicolumn{2}{|c|}{$4.1 \pm 1.94$} \\
\hline Minimum & \multicolumn{2}{|c|}{ I day } \\
\hline Maximum & \multicolumn{2}{|c|}{10 days } \\
\hline \multicolumn{3}{|l|}{ Hematologic parameters (mean \pm SD) } \\
\hline White blood cells $\left(10^{9} / \mathrm{l}\right)$ & \multicolumn{2}{|c|}{$17.1 \pm 7$} \\
\hline Hemoglobin $(g / d l)$ & \multicolumn{2}{|c|}{$8.2 \pm 1.5$} \\
\hline Platelets $\left(10^{9} / \mathrm{l}\right)$ & \multicolumn{2}{|c|}{$380.7 \pm 301.4$} \\
\hline Reticulocyte count (\%) & \multicolumn{2}{|c|}{$5.5 \pm 2.2$} \\
\hline
\end{tabular}

Regarding the relation between the causes of admissions and gender, we found no significant difference between males and females regarding the different causes of hospital admissions ( $p>0.05$ ). Also, we did not find any significant difference between Saudi and non-Saudi children regarding the causes of admissions ( $p>0.05$ ). Analyzing the causes of admissions in relation to age groups, we found a significant higher percent of painful crises (VOC) $(p=0.02)$, limb pain $(p=0.027)$ and back pain $(\mathrm{p}=0.042)$ among children $>7$ to 14 years old. However, infection was significantly higher among children less than 7 years old $(\mathrm{p}=0.003)$ (Table 2).

The median (IQR) length hospital stay among children with SCA was 4 (2) days. We statistically analyzed the length of hospital stay in relation to age groups, gender, 


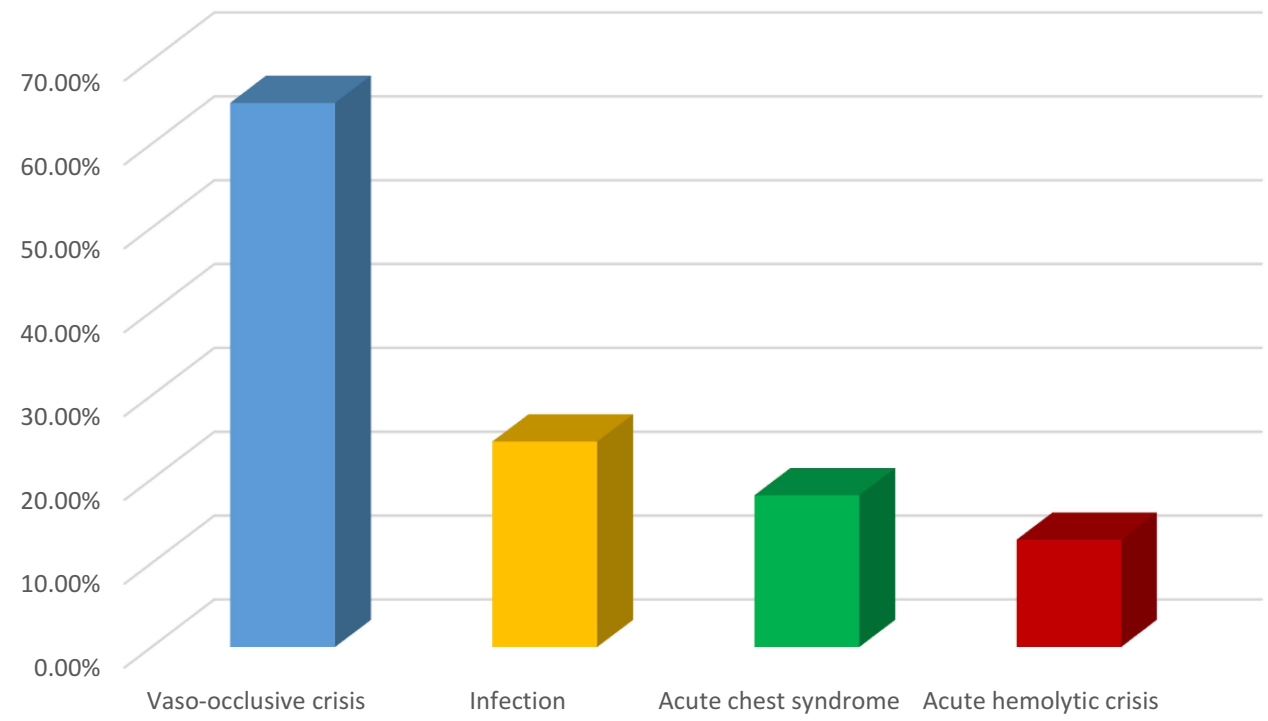

Figure I Bar-chart showed the different causes of admissions among children with SCA.

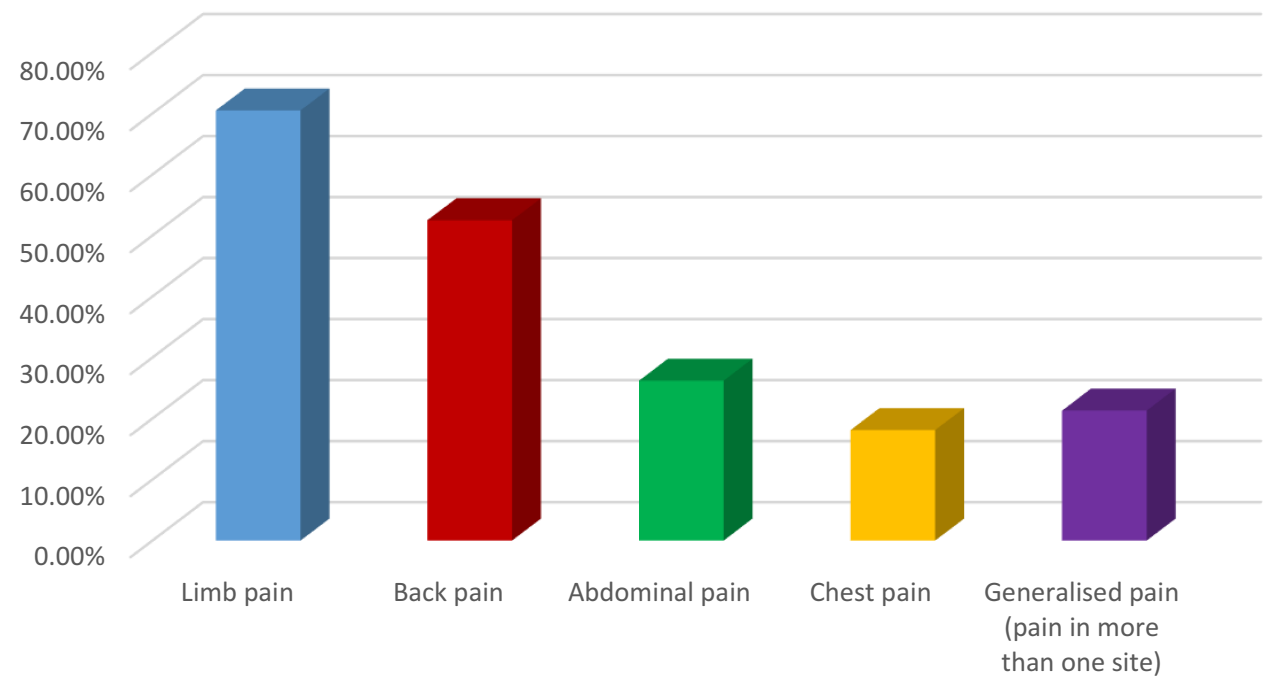

Figure 2 Bar-chart showed the frequency of vaso-occlusive crisis by body region.

causes of admission and medications. We observed a significantly higher percent of children who stayed in the hospital for more than 4 days among children admitted due to infection $(\mathrm{p}=0.01)$ and ACS $(\mathrm{p}<0.001)$. Also, a significantly higher percent of children who were noncompliant to HU stayed for more than 4 days in the hospital $(\mathrm{p}=0.04)$ (Table 3$)$. Forty $(42.6 \%)$ children had history of recurrent hospital admissions ( $\geq 3$ admissions / year). We found a statistically significantly relation between recurrent hospital admissions and noncompliance to $\mathrm{HU}$ intake $(\mathrm{p}=0.002)$. However, there was no statistical relation between regular blood transfusions and frequency of hospital admissions $(\mathrm{p}=0.98)$.

\section{Discussion}

Chronic conditions such as SCA require frequent utilization of the health services at different levels. These services include screening, vaccinations, drugs, blood transfusion and hospitalizations for different reasons. All these measures are provided to reduce patients' morbidity and mortality but cause significant economic burden on the health system. ${ }^{14}$

Vaso-occlusive crisis is due to obstruction of the microcirculation by sickled red blood cells, leading to ischemic injury of the affected organ and pain. Painful crises represent the most distinguishing clinical feature of SCD and are the leading cause of emergency department 
Table 2 Relation Between Causes of Hospital Admissions and Age Group Among the Studied Group

\begin{tabular}{|c|c|c|c|}
\hline \multirow{2}{*}{$\begin{array}{l}\text { Clinical } \\
\text { Presentation }\end{array}$} & \multicolumn{2}{|c|}{ Age Group $(n=94)$} & \multirow[t]{2}{*}{ P-value } \\
\hline & $\begin{array}{c}<7 \text { Years } \\
(n=40)\end{array}$ & $\begin{array}{c}\geq 7 \text { Years } \\
(n=54)\end{array}$ & \\
\hline Painful crisis $(n=6 I)$ & 21 (34.4\%) & $40(65.6 \%)$ & $0.02 *$ \\
\hline Limb pain $(n=43)$ & $13(30.2 \%)$ & $30(69.8 \%)$ & $0.03 *$ \\
\hline Back pain $(n=32)$ & $9(28.1 \%)$ & 23 (7I.9\%) & $0.04 *$ \\
\hline Abdominal pain $(n=16)$ & 7 (43.8\%) & $9(56.2 \%)$ & 0.92 \\
\hline $\begin{array}{l}\text { Acute chest syndrome } \\
(n=17)\end{array}$ & 9 (52.9\%) & $8(47.1 \%)$ & 0.34 \\
\hline $\begin{array}{l}\text { Acute hemolytic crisis } \\
(n=12)\end{array}$ & 5 (4I.7\%) & 7 (58.3\%) & 0.95 \\
\hline Infections $(n=23)$ & $16(69.6 \%)$ & 7 (30.4\%) & $0.003 *$ \\
\hline Recurrent crisis $(n=40)$ & 15 (37.5\%) & 25 (62.5\%) & 0.39 \\
\hline
\end{tabular}

Notes: $\mathrm{n}=$ number, chi-square test; $*$ Significant value.

visits and hospital admissions for affected patients. ${ }^{15}$ The present study showed that VOC was the most common cause $(64.9 \%)$ of hospitalizations among children with SCD. These results are consistent with the studies done in Nigeria, Kuwait, Iraq, and Oman who reported VOC among $61.5 \%, 63.2 \%, 73.8 \%$ and $83 \%$ of their admitted patients respectively. ${ }^{7,16-18}$ Previous Saudi studies done in Al-Madinah Al-Munawarah and Makkah AlMukarramah reported similar results in which VOC was the main cause of hospitalizations among their studied group of patients with a percent of $49.7 \%$ and $55.9 \%$ respectively. ${ }^{11,19}$ VOC is considered one of the most common causes for hospitalizations in most of studies and this may be attributed to that those children are usually physically active without taking care of proper hydration which predisposes them to dehydration and thrombosis. ${ }^{20}$

The majority of children included in our study were presented with limb and back pains with a significantly higher frequency among children between 7 and 14 years old. Most children with SCA experience painful crisis, of variable severity and frequency, by the age of 6 years. Pain can affect any part of the body but frequently affects the extremities, back and chest areas. Bone pains in VOC result from infarction of the bone marrow, which usually involve bones where the bone marrow is active which varies according to the age of the patient. Acute dactylitis is the most common presentation in the first 18 months of life due to affection of the metatarsals and metacarpals. As the child grows older, pain often involves the long bones, sites that retain marrow activity during childhood.
Proximity to the joints and occasional sympathetic effusions lead to the belief that the pain involves the joints. ${ }^{19}$

In the present study, infection was the second cause of hospitalization among our patients. This was consistent with a study done in Basra, Iraq $^{7}$ who found that infections were the second common cause of hospitalizations with a percentage of $9.3 \%$. Regarding previous studies done in Saudi Arabia there were difference in the percentage of infection rates among patients with SCA. An earlier study done in Al-Madinah Al-Munawarah in 1998, infection was the second cause of hospital admissions with a percent of $67.9 \% .{ }^{5}$ However, in 2019 another study which was conducted at the Maternity and Children Hospital in AlMadinah Al-Munawarah reported a regression of infection to be the third cause of admissions with a percentage of $17.5 \% .{ }^{11}$ Patients with SCA have several factors that make them more liable to severe bacterial infections, however, the most important of which is poor splenic function. ${ }^{21}$

ACS is the most common cause of morbidity and mortality in children and adults with SCD. It accounts for about $25 \%$ of deaths and can follow VOC. It can be triggered by hypoxia due to hypoventilation of the chest caused by VOC. Also, it can also occur as a result of fat embolism originating from the distal bone in VOC. ${ }^{22}$ ACS was the third cause of admissions among our patients (18.1\%). This is consistent with previous studies done by Hawasawi et al in Saudi Arabia, ${ }^{5}$ and by Salman and Hassan in Iraq, who found ACS to be the third cause of admissions among their patients. ${ }^{7}$ In another study conducted in Kuwait, acute chest syndrome was the fourth reported cause of admissions among children with SCA $(6.6 \%){ }^{16}$

In the present study, we analyzed the relation between different causes of admissions and patient's age and sex. We did not find a significant relation between gender and different causes of hospital admissions among children with SCA. Similarly, Abd Elmoneim et a ${ }^{11}$ reported no significant difference between males and females regarding causes of hospitalization. When considering the causes of admissions in relation to age group, we found that painful crises, limb and back pains were significantly more common among children between 7 and 14 years old. However, infections were found to be significantly more in children $<7$ years old. Abd Elmoneim et $\mathrm{al}^{11}$ reported that younger children aged $<12$ years showed significantly high frequency of acute chest syndrome (26.5\%) but acute painful crisis $(66.4 \%)$ was significantly reported in older patients (age $\geq 12$ years). This may be 
Table 3 The Length of Hospital Stay in Relation to Different Factors

\begin{tabular}{|c|c|c|c|c|c|c|}
\hline \multicolumn{2}{|l|}{ Variables } & \multicolumn{4}{|c|}{ Length of Hospital Stay } & \multirow{5}{*}{$\begin{array}{c}\text { p-value } \\
0.847\end{array}$} \\
\hline & & \multicolumn{2}{|c|}{$\leq 4$ Days } & \multicolumn{2}{|c|}{$>4$ Days } & \\
\hline & & \multirow{3}{*}{$\begin{array}{ll}\text { Number } & \\
23 \\
35\end{array}$} & \multirow{3}{*}{$\begin{array}{l}\% \\
39.7 \% \\
60.3 \%\end{array}$} & \multirow{3}{*}{$\begin{array}{ll}\text { Number } & \\
15 \\
21\end{array}$} & \multirow{3}{*}{$\begin{array}{l}\% \\
41.7 \% \\
58.3 \%\end{array}$} & \\
\hline Gender & Females & & & & & \\
\hline & Males & & & & & \\
\hline Age groups & $<7$ years & 22 & $37.9 \%$ & 18 & $50.0 \%$ & 0.25 \\
\hline & $\geq 7$ years & 36 & $62.1 \%$ & 18 & $50.0 \%$ & \\
\hline \multirow[t]{2}{*}{ Nationality } & Non-Saudi & 26 & $44.8 \%$ & 17 & $47.2 \%$ & 0.821 \\
\hline & Saudi & 32 & $55.2 \%$ & 19 & $52.8 \%$ & \\
\hline \multirow[t]{2}{*}{ VOC } & No & 17 & $29.3 \%$ & 16 & $44.4 \%$ & 0.135 \\
\hline & Yes & 41 & $70.7 \%$ & 20 & $55.6 \%$ & \\
\hline \multirow[t]{2}{*}{ Limb pain } & No & 32 & $55.2 \%$ & 19 & $52.8 \%$ & 0.821 \\
\hline & Yes & 26 & $44.8 \%$ & 17 & $47.2 \%$ & \\
\hline \multirow[t]{2}{*}{ Back pain } & No & 34 & $58.6 \%$ & 28 & $77.8 \%$ & 0.057 \\
\hline & Yes & 24 & $41.4 \%$ & 8 & $22.2 \%$ & \\
\hline \multirow[t]{2}{*}{ Abdominal pain } & No & 49 & $84.5 \%$ & 29 & $80.6 \%$ & 0.622 \\
\hline & Yes & 9 & $15.5 \%$ & 7 & $19.4 \%$ & \\
\hline \multirow[t]{2}{*}{ Generalized pain } & No & 52 & $89.7 \%$ & 29 & $80.6 \%$ & 0.214 \\
\hline & Yes & 6 & $10.3 \%$ & 7 & $19.4 \%$ & \\
\hline \multirow[t]{2}{*}{ Infections } & No & 49 & $84.5 \%$ & 22 & $61.1 \%$ & $0.01 *$ \\
\hline & Yes & 9 & $15.5 \%$ & 14 & $38.9 \%$ & \\
\hline \multirow[t]{2}{*}{ ACS } & No & 55 & $94.8 \%$ & 22 & $61.1 \%$ & $<0.00 I^{*}$ \\
\hline & Yes & 3 & $5.2 \%$ & 14 & $38.9 \%$ & \\
\hline \multirow[t]{2}{*}{ Hemolytic crisis } & No & 48 & $82.8 \%$ & 34 & $94.4 \%$ & 0.099 \\
\hline & Yes & 10 & $17.2 \%$ & 2 & $5.6 \%$ & \\
\hline \multirow[t]{2}{*}{ Recurrent crisis } & No & 35 & $60.3 \%$ & 19 & $52.8 \%$ & 0.471 \\
\hline & Yes & 23 & $39.7 \%$ & 17 & $47.2 \%$ & \\
\hline \multirow[t]{2}{*}{ Ospen } & No & 39 & $67.2 \%$ & 18 & $50.0 \%$ & 0.096 \\
\hline & Yes & 19 & $32.8 \%$ & 18 & $50.0 \%$ & \\
\hline \multirow[t]{2}{*}{ Folic acid } & No & 19 & $32.8 \%$ & 14 & $38.9 \%$ & 0.55 \\
\hline & Yes & 39 & $67.2 \%$ & 22 & $61.1 \%$ & \\
\hline \multirow[t]{2}{*}{$\mathrm{HU}$} & No & 35 & $60.3 \%$ & 29 & $80.6 \%$ & $0.04 *$ \\
\hline & Yes & 23 & $39.7 \%$ & 7 & $19.4 \%$ & \\
\hline
\end{tabular}

Notes: chi-square test, *Significant value.

Abbreviations: VOC, vaso-occlusive crisis; ACS, acute chest syndrome; HU, hydroxyurea.

explained by that acute chest syndrome is probably triggered by chest infection and younger children are more susceptible to both chest infection in addition to gastroenteritis. $^{22}$

Regarding the length of hospital stay we found a higher rate of prolonged hospitalization ( $>4$ days) among children who were admitted with infection and ACS, as well as, among children who are non-compliant to HU. Similarly, Salman and Hassan reported that the use of HU was associated with shorter length of hospital stay and fewer hospital readmissions. ${ }^{7}$ Also, we found that noncompliance to $\mathrm{HU}$ was significantly related to recurrent hospital admissions. Previous studies showed that HU improves hematological parameters and has a role in the 
reduction of the complications related to SCD (mainly acute painful crises), the required hospitalizations, and the length of hospital stay. ${ }^{23,24}$

\section{Conclusion}

Forty $(42.6 \%)$ children had history of recurrent hospital admissions ( $\geq 3$ admissions /year). The most common cause of hospitalisation among children with SCD in a group of private hospitals in Jeddah, Saudi Arabia was VOC which reached up to $70 \%$. Other causes included in order; infection, ACS and acute anemia. The length of hospital stay was more prolonged among patients with infection and ACS. Non-compliance to medications was the main underlying factor for admission and prolonged stay at hospital. Physicians should pay more attention to patient education concerning the importance of good hydration especially in countries with warm weather, and the compliance to medications like oral penicillin $\mathrm{V}$ and hydroxyurea.

\section{Acknowledgments}

We would like to express our profound gratitude and deep regards to Professor Intessar Sultan, professor of internal medicine and the head of the research team at ISNC for her help and support in the statistical part of this research. Also, we would like to thank the staff members in the pediatric departments in Ibn Sina Hospital and Al Jedaani hospitals for their assistance during data collection.

\section{Disclosure}

The authors declare no conflicts of interest for this work.

\section{References}

1. Wali Y, Kini V, Yassin MA. Distribution of sickle cell disease and assessment of risk factors based on transcranial Doppler values in the Gulf region. Hematology. 2020;25(1):55-62. doi:10.1080/160784 54.2020 .1714113

2. Alhumaid AM, Aleidi AS, Alfakhri AS, et al. Clinical features and outcome of sickle cell anemia in a tertiary center: a retrospective cohort study. J Appl Hematol. 2018;9:22-28. doi:10.4103/joah. joah $48 \_17$

3. El-Hazmi MA, Al-Hazmi AM, Warsy AS. Sickle cell disease in Middle East Arab countries. Indian J Med Res. 2011;134(5):59 7-610. doi:10.4103/0971-5916.90984

4. Memish ZA, Owaidah TM, Saeedi MY. Marked regional variations in the prevalence of sickle cell disease and $\beta$-thalassemia in Saudi Arabia: findings from the premarital screening and genetic counseling program. J Epid and Global Health. 2011;1:61-68. doi:10.1016/j. jegh.2011.06.002

5. Hawasawi ZM, Nabi G, Al Magamci MS, et al. Sickle cell anemia in childhood in Madina. Ann Saudi Med. 1998;18:293-295. doi:10.5144/ 0256-4947.1998.293
6. Maf EH, Warsy AS. Hemoglobinopathies in Arab countries. In: Teebi AS, Farag TL, editors. Genetic Disorders Among Arab Populations. New York: Oxford University Press; 1997: 83-110.

7. Salman ZA, Hassan MK. Hospitalization events among children and adolescents with sickle cell disease in Basra, Iraq. Anemia. 2015;25 (5):55-62.

8. McClish DK, Penberthy LT, Bovbjerg VE, et al. Health related quality of life in sickle cell patients: the PiSCES project. Health Qual Life Outcomes. 2005;3:50. doi:10.1186/1477-7525-3-50

9. Anie KA. Psychological complications in sickle cell disease. $\mathrm{Br}$ $J$ Haematol. 2005;129:723-729. doi:10.1111/j.1365-2141.2005.05 500.x

10. Bhagat VM, Baviskar SR, Mudey AB, et al. Poor health related quality of life among patients of sickle cell disease. Indian J Palliat Care. 2014;20(2):107-111. doi:10.4103/0973-1075.132622

11. Abd Elmoneim AA, Al Hawsawi ZM, Mahmoud BZ, et al. Causes of hospitalization in sickle cell diseased children in western region of Saudi Arabia. A single center study. Saudi Med J. 2019;40 (4):401-404. doi:10.15537/smj.2019.4.24049

12. Alsulami SH, Alotaibi MN, Alfaraj EA, et al. Evaluation of the most common complications of sickle cell anemia and management in children: simple literature review. EJHM. 2018;72(2):3951-3960. doi:10.21608/ejhm.2018.9076

13. Platt OS, Thorington BD, Brambilla DJ, et al. Pain in sickle cell disease. Rates and risk factors. $N$ Engl J Med. 1991;325(1):11-16. doi:10.1056/NEJM199107043250103

14. Kauf TL, Coates TD, Huazhi L, et al. The cost of health care for children and adults with sickle cell disease. AJH. 2018;84 (6):323-327.

15. Madigan C, Malik P. Pathophysiology and therapy for haemoglobinopathies. Part I: sickle cell disease. Expert Rev Mol Med. 2006;8 (9):1-23. doi:10.1017/S1462399406010659

16. Akar NA, Adekile A. Ten-year review of hospital admissions among children with sickle cell disease in Kuwait. Med Princ Pract. 2008;17 (5):404-408. doi:10.1159/000141506

17. Jaiyesimi F, Pandey R, Bux D, et al. Sickle cell morbidity profile in Omani children. Ann Trop Paediatr. 2002;22(1):45-52. doi:10.1179/ 027249302125000148

18. Brown BJ, Jacob NE, Lagunju IA, et al. Morbidity and mortality pattern in hospitalized children with sickle cell disorders at the University College Hospital, Ibadan, Nigeria. Niger $J$ Pediatr. 2013;40(1):34-39.

19. Alkot M, Almaghrabi WA, Al-Najdi N, et al. Prevalence of complications of sickle cell disease at Makkah Al-Mukaramah, Saudi Arabia, 2017. Ann Clin Lab Res. 2018;6(1):226. doi:10.21767/ 2386-5180.1000226

20. Yale SH, Nagib N, Guthrie T. Approach to the vasoocclusive crisis in adults with sickle cell disease. Am Fam Physician. 2000;61: 1349-1356.

21. Booth $\mathrm{C}$, Inusa $\mathrm{B}$, Obaro SK. Infection in sickle cell disease: a review. Int $J$ Infect Dis. 2010;14:e2-e12. doi:10.1016/j.ijid.2009. 03.010

22. Howard J, Hart N, Roberts-Harewood M, et al. Guideline on the management of acute chest syndrome in sickle cell disease. $\mathrm{Br}$ J Haematol. 2015;169:492-505. doi:10.1111/bjh.13348

23. Ballas SK, Bauserman RL, McCarthy WF, et al. Hydroxyurea and acute painful crises in sickle cell anemia: effects on hospital length of stay and opioid utilization during hospitalization, outpatient acute care contacts, and at home. J Pain Symptom Manage. 2010;40 (6):870-882. doi:10.1016/j.jpainsymman.2010.03.020

24. Mulaku M, Opiyo N, Karumbi J, et al. Evidence review of hydroxyurea for the prevention of sickle cell complications in low-income countries. Arch Dis Child. 2013;98(11):908-914. doi:10.1136/archdischild-2012-302387 


\section{Publish your work in this journal}

The Journal of Blood Medicine is an international, peer-reviewed, open access, online journal publishing laboratory, experimental and clinical aspects of all aspect pertaining to blood based medicine including but not limited to: Transfusion Medicine; Blood collection, Donor issues, Transmittable diseases, and Blood banking logistics; Immunohematology; Artificial and alternative blood based therapeutics; Hematology; Biotechnology/nanotechnology of blood related medicine; Legal aspects of blood medicine; Historical perspectives. The manuscript management system is completely online and includes a very quick and fair peer-review system. Visit http://www.dovepress.com/testimonials.php to read real quotes from published authors. 